\title{
Respiratory function in progressive systemic sclerosis
}

\author{
MARY CATTERALL AND N.R. ROWELL \\ From the Departments of Thoracic Surgery and Dermatology, General Infirmary, Leeds
}

In progressive systemic sclerosis, sometimes referred to as generalized scleroderma, atrophic and sclerotic changes in the skin and internal organs are usually preceded by Raynaud's phenomenon. The disorder, which affects women more frequently than men, forms one of the socalled collagen vascular diseases and, although the aetiology is uncertain, there is evidence to suggest that auto-immune mechanisms are involved (Fennell, Rodnan and Vazquez, 1962 ; Rowell, 1962 ; Rowell and Beck, 1963).

The cutaneous manifestations, which are called acrosclerosis, involve mainly the face, hands, and

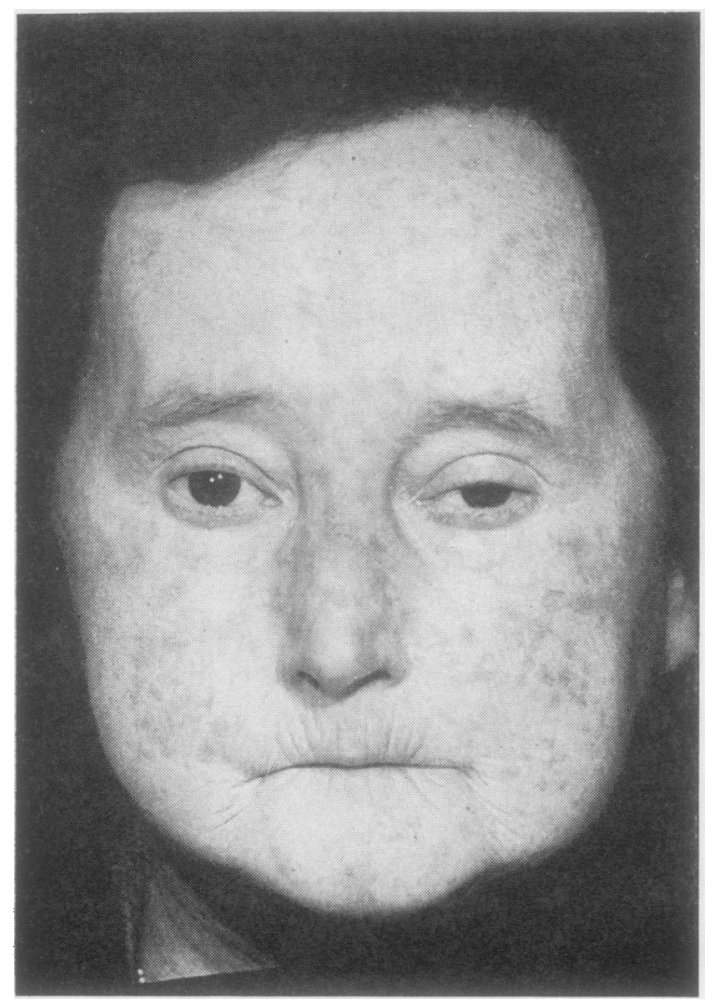

FIG. 1. The face of patient 1 showing typical changes. feet. Atrophy of the tissues of the face gives a shrunken, tight, and shiny appearance with a beaked nose and small mouth opening, around which there is radial furrowing (Fig. 1). The hands (Fig. 2) and, to a lesser extent, the feet show characteristic changes. Atrophy occurs first in the terminal phalanges, and spreads proximally to give tapering digits. The nails curve over the ends of the fingers and painful ulcers and whitlows are frequent. The skin of the fingers and hands is smooth and bound down to the deeper structures. The hands become fixed in a position of semiflexion and eventually may become very small.

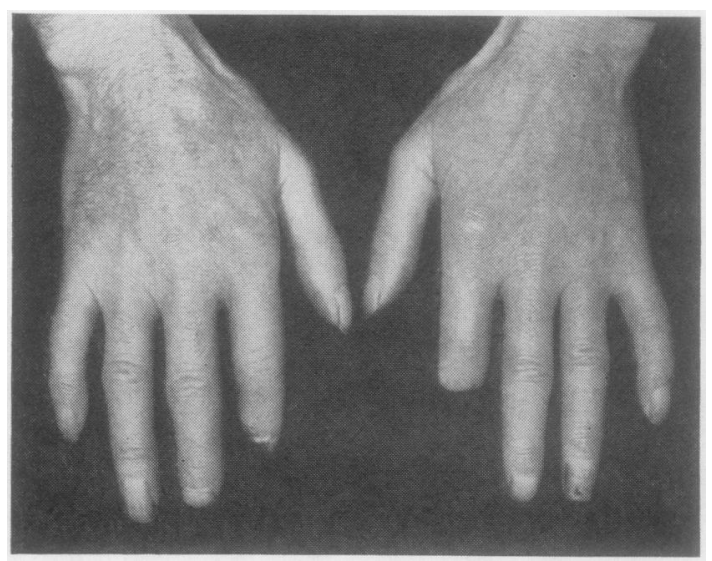

FIG. 2. The hands of patient 15 showing typical changes in the terminal phalanges and amputation of the left index finger.

Striking macular telangiectases occur on the face, upper chest, and hands. Hyperpigmentation and calcinosis are frequent. Sclerosis may progress to the neck, chest, and forearms but seldom spreads more proximally.

Widespread systemic changes occur, but the order and extent of the involvement of individual organs vary. In addition to the pulmonary changes, the gastrointestinal tract is frequently involved with dilatation and absent peristalsis in the oesophagus, 
duodenal ileus, malabsorption from the small intestine, and colonic diverticula. The myocardium may show diffuse fibrosis. Impairment of renal function with death from uraemia or malignant hypertension also occurs. Muscle changes, identical with those seen in dermatomyositis or polymyositis, are well recognized, but involvement of the central nervous system is rare.

The association of pulmonary fibrosis and scleroderma was noted by Finlay in 1891, and later Matsui (1924) described the pathological changes in the lungs. Diffuse reticular shadowing in the lower two-thirds of the lung fields is the earliest radiological change. Sometimes nodular changes occur, and very occasionally the apices may be involved (Nice, Menon, and Rigler, 1959). Small cysts are frequent and, if extensive, may give rise to the appearances of honeycomb lung.

Pulmonary function studies in progressive systemic sclerosis were first reported by Baldwin, Cournand, and Richards (1949). They found reduction in lung volumes and low arterial oxygen saturation associated with hyperventilation in three patients with progressive systemic sclerosis in a series of 39 patients with pulmonary fibrosis. Similar observations have been made by others (Spain and Thomas, 1950 ; West, McClement, Carroll, Bliss, Kuschner, Richards, and Cournand, 1951 ; Salomon, Appel, Dougherty, Herschfus, and Segal, 1955; Marks, Cugell, Cadigan, and Gaensler, 1957 ; Miller, Fowler, and Helmholz,
1959 ; Tranquada, Simmons, and Miller, 1960), but these investigations were made on relatively few patients and using a limited range of tests of respiratory function.

The study to be described was designed to measure the ventilation, lung volumes, and diffusing capacity of 16 patients with progressive systemic sclerosis of varying severity. Blood gas analyses were not made because gas tensions are altered only after the patient's compensatory mechanisms have failed and usually when extensive changes have already occurred in the lungs.

\section{MATERIAL AND METHOD}

Thirteen women and three men, whose ages ranged from 26 to 59 years, were studied. The extent of the systemic changes in the gastrointestinal tract had been investigated radiologically, and in the kidney by renal function tests including urea clearance. The results of these findings are summarized in Table $\mathrm{I}$.

A full history was taken and a clinical examination carried out on all the patients. A chest radiograph and an electrocardiogram were taken. The results of these investigations are shown in Table II.

All except two patients underwent full respiratory function tests. One of these two (patient 6) had such a severe deformity of the mouth that the mouthpiece could not be inserted, and modified tests had to be performed using a face mask. Patient 2 was too breathless to perform the tests of mechanical efficiency and the diffusing capacity.

\section{TABLE I}

\begin{tabular}{|c|c|c|c|c|c|c|c|c|c|c|c|c|c|}
\hline \multirow[b]{3}{*}{ Patient } & \multirow[b]{3}{*}{ Age } & \multirow[b]{3}{*}{$\operatorname{Sex}$} & \multirow[b]{3}{*}{$\begin{array}{l}\text { Raynaud's } \\
\text { Phenom- } \\
\text { enon }\end{array}$} & \multirow[b]{3}{*}{$\begin{array}{l}\text { Duration } \\
\text { of } \\
\text { Raynaud's } \\
\text { Phenom- } \\
\text { enon (yr.) }\end{array}$} & \multirow[b]{3}{*}{$\begin{array}{l}\text { Acro- } \\
\text { sclero- } \\
\text { sis }\end{array}$} & \multicolumn{6}{|c|}{ Involvement of } & \multirow[b]{3}{*}{$\begin{array}{l}\text { Hyper- } \\
\text { tension }\end{array}$} & \multirow[b]{3}{*}{ Other Features } \\
\hline & & & & & & \multicolumn{2}{|l|}{ Chest } & \multirow[b]{2}{*}{$\begin{array}{l}\text { Oeso- } \\
\text { phagus }\end{array}$} & \multirow[b]{2}{*}{$\begin{array}{l}\text { Rest of } \\
\text { Gastro- } \\
\text { intestinal } \\
\text { Tract }\end{array}$} & \multirow[b]{2}{*}{ Heart } & \multirow[b]{2}{*}{ Kidney } & & \\
\hline & & & & & & $\begin{array}{l}\text { Radio- } \\
\text { graph }\end{array}$ & Function & & & & & & \\
\hline 1 & 57 & $\mathbf{F}$ & + & 25 & + & + & + & + & & - & + & 一 & $\begin{array}{l}\text { Leg ulcer, amputa- } \\
\text { tion of leg }\end{array}$ \\
\hline 2 & 45 & $\mathbf{F}$ & + & 20 & + & + & + & + & & - & - & - & $\begin{array}{l}\text { Leg ulcer, diag- } \\
\text { nosed initially as } \\
\text { pulmonary } \mathrm{Tb} \text {, } \\
\text { died later }\end{array}$ \\
\hline 3 & 39 & $\mathbf{F}$ & + & 19 & + & + & + & + & & + & - & + & $\begin{array}{l}\text { Erythema nodo- } \\
\text { sum-like lesions, } \\
\text { died later }\end{array}$ \\
\hline 4 & 40 & $\mathbf{M}$ & + & 17 & + & - & + & + & $\begin{array}{l}\text { Small } \\
\text { intestine }\end{array}$ & - & + & + & Leg ulcer, \\
\hline $\begin{array}{l}5 \\
6\end{array}$ & $\begin{array}{l}53 \\
49\end{array}$ & $\underset{\mathbf{F}}{\mathbf{M}}$ & $\begin{array}{l}+ \\
+\end{array}$ & $\begin{array}{l}4 \\
5\end{array}$ & $\dot{t}$ & \pm & + & $\begin{array}{l}+ \\
+\end{array}$ & Duodenum & $\begin{array}{l}+ \\
+\end{array}$ & $\overline{+}$ & \pm & $\begin{array}{l}\text { Died later } \\
\text { Diagnosed initially } \\
\text { as pulmonary } \mathrm{Tb}\end{array}$ \\
\hline $\begin{array}{r}7 \\
8 \\
9 \\
10 \\
11 \\
12 \\
13 \\
14 \\
15 \\
16\end{array}$ & $\begin{array}{l}48 \\
59 \\
52 \\
39 \\
30 \\
53 \\
47 \\
40 \\
41 \\
26\end{array}$ & $\begin{array}{l}\mathbf{F} \\
\mathbf{F} \\
\mathbf{F} \\
\mathbf{F} \\
\mathbf{F} \\
\mathbf{F} \\
\mathbf{F} \\
\mathbf{F} \\
\mathbf{M} \\
\mathbf{F}\end{array}$ & $\begin{array}{l}+ \\
+ \\
+ \\
+ \\
+ \\
+ \\
+ \\
+ \\
+ \\
+\end{array}$ & $\begin{array}{r}3 \\
11 \\
12 \\
10 \\
5 \\
12 \\
10 \\
5 \\
3\end{array}$ & $\begin{array}{l}+ \\
+ \\
+ \\
+ \\
+ \\
+ \\
+ \\
+ \\
+ \\
+\end{array}$ & $\begin{array}{l} \pm \\
- \\
\overline{+} \\
\overline{+} \\
\overline{-} \\
\overline{+} \\
\overline{-}\end{array}$ & $\begin{array}{l}+ \\
+ \\
+ \\
+ \\
+ \\
+ \\
+ \\
+ \\
+ \\
+\end{array}$ & $\begin{array}{l}+ \\
+ \\
\overline{+} \\
- \\
\overline{+} \\
\pm \\
+ \\
+\end{array}$ & $\begin{array}{l}\text { Duodenum } \\
\text { Colon }\end{array}$ & $\begin{array}{l}- \\
\overline{+} \\
\overline{-} \\
\overline{+} \\
\overline{+} \\
\overline{+}\end{array}$ & $\begin{array}{l}- \\
\overline{-} \\
- \\
- \\
\overline{+} \\
+ \\
\overline{-}\end{array}$ & $\begin{array}{l} \pm \\
- \\
- \\
- \\
- \\
- \\
+ \\
-\end{array}$ & \\
\hline
\end{tabular}


TABLE II

\begin{tabular}{|c|c|c|c|c|c|c|c|c|c|}
\hline & Group & Patient & Age & $\underset{(l .)}{V . C .}$ & $\stackrel{\%}{\%}$ & $\begin{array}{l}\text { R.V./ } \\
\text { T.L.C. }\end{array}$ & DL & Chest Radiograph & Electrocardiogram \\
\hline \multirow[t]{7}{*}{$\mathbf{A}$} & \multirow[t]{7}{*}{$\begin{array}{l}\text { Main } \\
\text { complaint } \\
\text { dyspnoea }\end{array}$} & 1 & 57 & 1.42 & 77 & 39 & $\begin{array}{l}38 \\
(8)\end{array}$ & $\begin{array}{l}\text { Left diaphragm elevated, partly fixed } \\
\text { by lateral adhesions; fine mottling } \\
\text { both lower zones but no definite cystic } \\
\text { change }\end{array}$ & Normal \\
\hline & & 2 & 45 & 0.6 & 一 & 53 & - & $\begin{array}{l}\text { Multiple cavities both lung fields a few } \\
\text { mm. to } 3 \mathrm{~cm} \text {. in diameter, coarse } \\
\text { honeycomb appearance in lower zones, } \\
\text { pleural thickening, no normal lung tissue }\end{array}$ & Normal \\
\hline & & 3 & 39 & $1 \cdot 84$ & 98 & 52 & \multirow{2}{*}{$\begin{array}{l}21 \\
(4) \\
15 \\
(4)\end{array}$} & \multirow{3}{*}{$\begin{array}{l}\text { Slight increase in linear markings of } \\
\text { both lower lung fields } \\
\text { Left diaphragm slightly elevated and } \\
\text { fixed, no significant changes in lung } \\
\text { fields } \\
\text { Fine punctate opacities, which may be } \\
\text { vascular, mostly in right lower and } \\
\text { mid zones, also in left base }\end{array}$} & Normal \\
\hline & & 4 & 40 & $2 \cdot 9$ & 89 & 37 & & & Normal \\
\hline & & 5 & 53 & $2 \cdot 15$ & 60 & 45 & $\begin{array}{l}29 \\
(7)\end{array}$ & & \multirow{3}{*}{$\begin{array}{l}\text { Grossly abnormal, prolonged P.R. } \\
\text { interval, notching of P wave, } \\
\text { ventricular ectopic beats, extensive } \\
\text { S.T. changes both surfaces of heart } \\
\text { Low voltage, S.T. depression V.4 } \\
\text { and } 6\end{array}$} \\
\hline & & 6 & 49 & $1 \cdot 3$ & 70 & - & - & $\begin{array}{l}\text { Some left apical fibrosis and slight } \\
\text { elevation of hilar shadow, remaining } \\
\text { lung fields normal }\end{array}$ & \\
\hline & & Mean & 47 & $1 \cdot 7$ & 79 & 45 & 26 & & \\
\hline \multirow[t]{7}{*}{ B } & \multirow[t]{7}{*}{$\begin{array}{l}\text { Dyspnoeic } \\
\text { on } \\
\text { exertion }\end{array}$} & 7 & 48 & $2 \cdot 54$ & 89 & 36 & $\begin{array}{l}43 \\
(10)\end{array}$ & \multirow{2}{*}{$\begin{array}{l}\text { Left lower lobe shows changes of reti- } \\
\text { culation and cystic change, rest of } \\
\text { lung fields normal } \\
\text { Normal }\end{array}$} & Normal \\
\hline & & 8 & 59 & $2 \cdot 4$ & 81 & 48 & \multirow{3}{*}{$\begin{array}{l}37 \\
(8) \\
61 \\
(14) \\
52 \\
(13)\end{array}$} & & Not performed \\
\hline & & 9 & 52 & $3 \cdot 25$ & 62 & 31 & & \multirow{3}{*}{$\begin{array}{l}\text { Both lung fields appear emphysema- } \\
\text { tous but no infiltration seen } \\
\text { Slight fibrosis anterior basal segment } \\
\text { right lung, rest of right lung and left } \\
\text { lung clear } \\
\text { Normal }\end{array}$} & \multirow{2}{*}{$\begin{array}{l}\text { Low voltage, prominent } U \text { wave } \\
\text { in left ventricular leads } \\
\text { Ventricular ectopic beats, abnor- } \\
\text { mal } Q \text { wave in lead } 3\end{array}$} \\
\hline & & 10 & 39 & $2 \cdot 5$ & 80 & 32 & & & \\
\hline & & 11 & 30 & $3 \cdot 48$ & 60 & 33 & \multirow{2}{*}{$\begin{array}{l}49 \\
(14) \\
68 \\
(15)\end{array}$} & & Normal \\
\hline & & 12 & 53 & $2 \cdot 34$ & 77 & 39 & & $\begin{array}{l}\text { Lung fields clear except for slight } \\
\text { increase in peripheral markings at } \\
\text { base, especially in left lung }\end{array}$ & Normal \\
\hline & & Mean & 47 & $2 \cdot 75$ & 75 & 36 & 52 & & \\
\hline \multirow[t]{5}{*}{$\mathbf{C}$} & \multirow{5}{*}{$\begin{array}{l}\text { No } \\
\text { complaint } \\
\text { of } \\
\text { dyspnoea }\end{array}$} & 13 & 47 & $2 \cdot 64$ & 84 & 40 & \multirow{3}{*}{$\begin{array}{l}57 \\
(11) \\
62 \\
(13) \\
32 \\
(6 \cdot 5)\end{array}$} & \multirow{5}{*}{$\begin{array}{l}\text { A few fibrotic strands from hila to } \\
\text { diaphragm, lung fields clear } \\
\text { Right diaphragm slightly elevated, } \\
\text { lung fields normal } \\
\text { Reticulation both lower zones, honey- } \\
\text { comb appearance right middle lobe } \\
\text { and posterior basal segments of both } \\
\text { lower lobes } \\
\text { Normal }\end{array}$} & \multirow{2}{*}{$\begin{array}{l}\text { Bifid } \mathbf{P} \text { waves in } \mathbf{I}, \mathbf{I I} \text {, and } \mathrm{A} . \mathrm{V} . \mathrm{F} \text {., } \\
\text { low voltage, flat } \mathbf{T} \text { waves } \\
\text { Normal }\end{array}$} \\
\hline & & 14 & 40 & $1 \cdot 86$ & 97 & 40 & & & \\
\hline & & 15 & 41 & $3 \cdot 06$ & 95 & 28 & & & $\begin{array}{l}\text { Suggestion of right ventricular } \\
\text { strain }\end{array}$ \\
\hline & & 16 & 26 & $3 \cdot 11$ & 92 & 29 & \multirow{2}{*}{$\begin{array}{l}58 \\
(16) \\
52\end{array}$} & & \multirow[t]{2}{*}{ Normal } \\
\hline & & Mean & 39 & $2 \cdot 67$ & 92 & 34 & & & \\
\hline
\end{tabular}

V.C. = vital capacity; \%V.C.=percentage of vital capacity expired in 1 second; R.V./T.L.C.=percentage of total lung capacity occupied by the residual volume; $\mathrm{DL}=$ diffusing capacity expressed as percentage of predicted normal; $\mathrm{DL}_{\mathrm{L}}(\mathrm{)})=\mathrm{diffusing}$ capacity expressed in ml./mm. $\mathrm{Hg} / \mathrm{min}$.

VENTILATION These tests were made on a Godart Pulmotest with the patient in the sitting position. The tidal volume and respiratory rate and the vital capacity were obtained, followed by the forced expiratory volume in one second and the percentage of vital capacity expired in one second. The maximum voluntary ventilation was performed for about 15 seconds at 40 respirations per minute.

THE LUNG Volumes These were obtained, using the same apparatus, by the helium dilution method. The measurements made were the inspiratory and expiratory components of the vital capacity, residual volume. functional residual capacity, and total lung capacity.

THE DIFFUSING CAPACITY The single breath method of Ogilvie, Forster, Blakemore, and Morton (1957), using $0.2 \%$ carbon monoxide in air containing $10 \%$ helium, was used in all cases. Two separate and individual tests were made on each patient on each occasion and the results were within $10 \%$ of the mean.
The results were given in $\mathrm{ml} . / \mathrm{mm}$. $\mathrm{Hg} / \mathrm{min}$. and were also expressed as percentages of predicted normal. This was calculated according to body surface area, as described by Ogilvie et al. (1957), and no regression factor for age was included. Normal subjects were tested routinely each week and the reproducibility of these results was within $\pm 5 \%$ of the mean.

\section{RESULTS}

CLINICAL FEATURES OF PULMONARY INVOLVEMENT The main complaint of six patients, patients 1 to 6 referred to as group A, was of dyspnoea; this was so severe as to make them virtually respiratory cripples. Six patients, patients 7 to 12 comprising group B, had been dyspnoeic on exertion for periods varying from six months to three years. Four patients, patients 13 to 16 referred to as group $\mathrm{C}$, had no complaint of dyspnoea even though they were leading fairly active lives. 
Patients 1 and 2 complained of cough, but this was denied in all the others. Patients 2 and 6 had been treated for pulmonary tuberculosis for 10 and 5 years respectively. This diagnosis had been made on radiological evidence and tubercle bacilli had never been found.

Examination of the respiratory system of these patients showed that none had clubbing of the fingers or toes. Cyanosis at rest was present only in patient 5. Three of those in group A were dyspnoeic at rest and hyperventilating. Movement, if present at all, was equal on both sides of the chest. The percussion note was not impaired over the lung fields in any patient. On auscultation breath sounds were vesicular, with no added sounds, in all except patient 5 , in whom coarse crepitations and whispering pectoriloquy were heard at the left base.

ELECTROCARDIOGRAPHY Abnormalities were present in six patients but showed no consistent pattern, and right ventricular strain was seen only once. Details are given in Table II. Nine patients had normal tracings.

RADIOLOGY Table II shows the radiological findings, together with the electrocardiographic results and the significant points of the respiratory function tests.

Five patients had diffuse changes in both lung fields. These changes varied from a honeycomb appearance and reticulation in patient 15 (Fig. 3) and cystic changes in patient 2 to diffuse fine mottling in patient 1 . They were always most marked in the lower zones and this distribution applied to the less marked changes in patient 12 , where the peripheral markings were increased at both bases.

Local fibrosis was present in the anterior basal segment of the right lung in patient 10 and in the left apex in patient 6 . In patient 13 fibrotic strands extended from the hilar region to the diaphragm, but the lung fields were clear. In patient 4 the dome of the left diaphragm was raised, but the lung fields were clear.

Patient 2 showed the greatest changes and these consisted of multiple cavities and coarse honeycomb formation (Fig. 4). She was one of those patients originally thought to have pulmonary tuberculosis.

Six patients had normal chest radiographs.

RESPIRATORY FUNCTION In Table II three measurements which reflect ventilation, the vital capacity, the percentage of the vital capacity expired in one second, and the percentage of the total lung

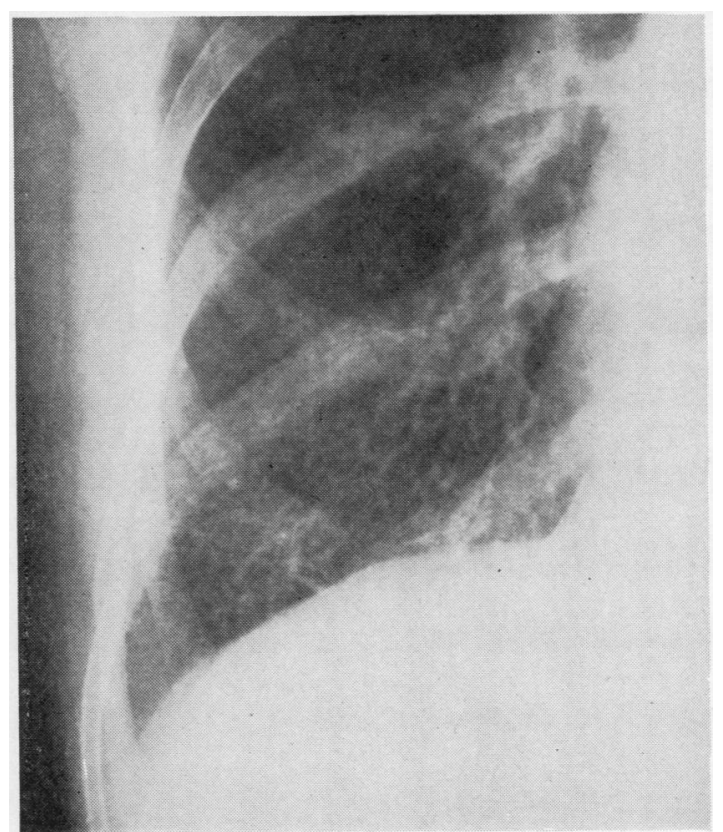

FIG. 3. Chest radiograph of patient 15 showing honeycomb appearance of the right lower zone.

capacity occupied by the residual volume, and the age and diffusing capacity are placed in the three groups $\mathrm{A}, \mathrm{B}$, and $\mathrm{C}$.

The numbers in each group are too small to be statistically significant, but they show that the vital capacity of patients in group A varied from 2.9 to 0.6 litres, mean 1.7 litres, while in group B it varied from 3.48 to 2.34 litres, mean 2.75 litres, and in group $\mathrm{C}$ from $3 \cdot 11$ to 1.86 litres, mean 2.67 litres.

In only three cases did the residual volume occupy more than $45 \%$ of the total lung capacity. In four cases it was reduced to 1.25 litres, but the rest had residual volumes within normal limits.

The total lung capacity was less than 5 litres in all but one of the patients.

In group $C$ only one patient had a reduced vital capacity, and all the patients in this group were remarkable for the high percentage of vital capacity which they could expire in one second, the average for the group being $92 \%$. Three patients in groups $\mathbf{A}$ and $\mathbf{B}$ could expire only $60 \%$ of their vital capacity in one second, and this test was performed more efficiently than the maximum voluntary ventilation, which was reduced in six patients.

The diffusing capacity was reduced in all patients. It was less than $40 \%$ of predicted normal in six, 40 to $60 \%$ in five, and 60 to $70 \%$ in three. 


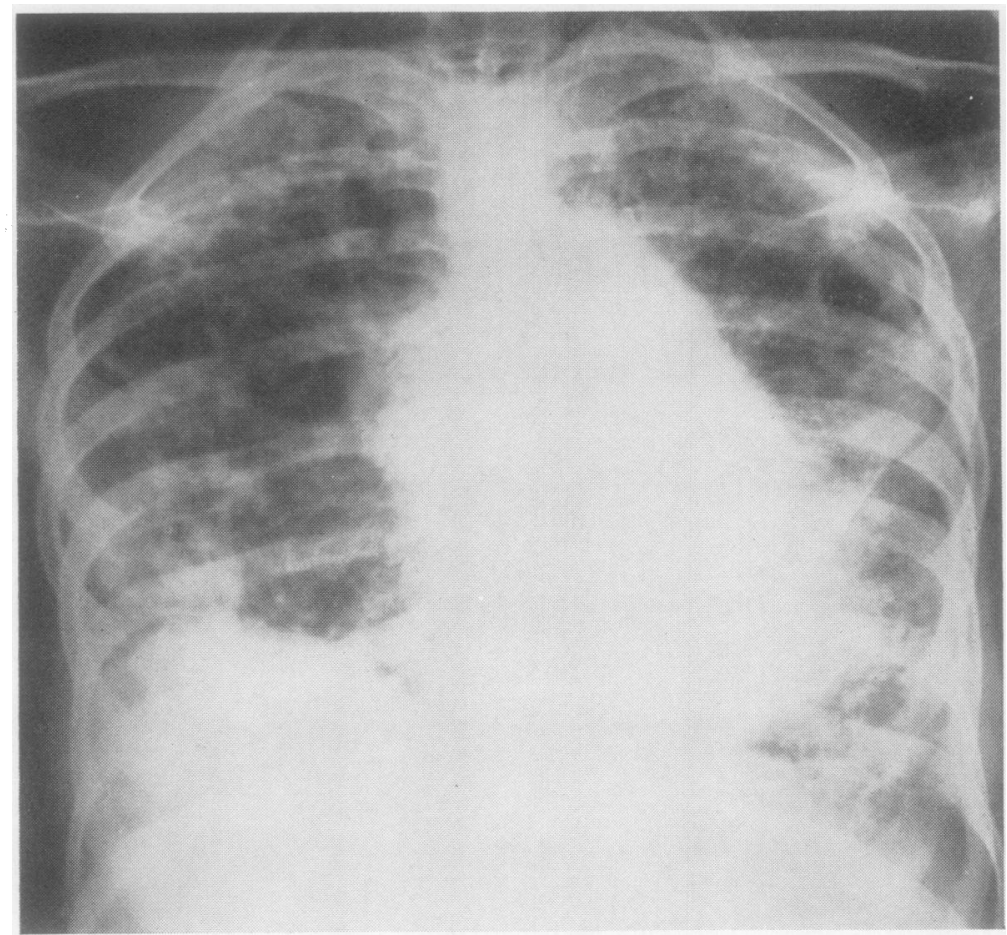

FIG. 4. Chest radiograph of patient 2 showing multiple cavities, coarse honeycombing, pleural thickening, and no normal lung tissue.

In group $\mathbf{A}$ patients the mean diffusing capacity was $26 \%$ of predicted normal. In the other two groups it was $52 \%$ of predicted normal.

Three patients died during the investigation and necropsy confirmed the presence of a diffuse fibrotic process throughout the lungs in all three.

\section{DISCUSSION}

In all the patients with systemic sclerosis the first symptom had been coldness of the fingers, but in six of them the main complaint, at the time of the respiratory function tests, was of shortness of breath. This was so marked that it was more incapacitating than the considerably deformed fingers and hands (see Fig. 2).

Cough was absent in all except two patients. This contrasts with the findings of Miller et al. (1959), seven of whose patients complained of cough, and with many other diseases such as radiation fibrosis, asbestosis, and carcinomatosis lymphangiosa, which have similar patterns of respiratory dysfunction and in which an irritating, non-productive cough is often a major symptom.

The similarity of the pattern of respiratory dysfunction in all these patients was striking, and so was its correlation with increasing dyspnoea. This was in contrast with the variability of the involvement of other organs, and also with the electrocardiographic results and the radiological appearances. The outstanding similarities of respiratory dysfunction in all three groups were a low diffusing capacity and the absence of airway obstruction as judged by the percentage of vital capacity which could be expired in one second. There were three patients in whom this was slightly below normal, but in the rest it was normal, and five patients were able to expire more than $90 \%$ of their vital capacity in one second, the normal being $80 \%$. No patient had more than small localized skin lesions over the thorax, and these were not sufficient to interfere with the movement of the chest wall or to restrict the vital capacity.

Patients 1 to 6 and patient 14 had reduced vital capacities and reduced total lung capacities, but in the remaining nine patients the vital capacity was within normal limits and there was no evidence of a restrictive process. In patients 1 to 4 the duration of the disease was $25,20,19$, and 17 years, and in patient 14 it was 10 years. There was therefore evidence that, as the disease 
progressed, it caused restriction of the lung volumes. Exceptions to this were patients 5 and 6 , who had suffered from the disease for only four and five years, but patient 5 was tested when he had a resolving pneumonia of both bases, and patient 6 had been diagnosed as having tuberculosis and had been in a sanatorium receiving collapse therapy and a phrenic crush, and these measures had clearly influenced the lung volumes. Patients 8, 9, and 10 had had the disease for 11, 12 , and 10 years with no restriction of lung volumes, but even so we think that progress of the disease is shown by restriction of the lung volumes. Patients with restricted lung volumes also had very low diffusing capacities, suggesting that a diffuse, fibrotic process was affecting the lungs at the alveolar-capillary level.

The diffusing capacity was less than $50 \%$ of predicted normal in eight patients, in six others it was between $50 \%$ and $70 \%$, and in two patients it could not be measured due to mouth deformity (patient 6) and extreme dyspnoea (patient 2). There was some correlation between impairment of diffusing capacity and length of history ; all those (except patient 12) who had a history of longer than 10 years had diffusing capacities of less than $50 \%$ of normal.

The practical significance of the results of the diffusing capacity test was that in seven patients it was the only objective sign that the lungs were involved in the disease, the chest radiographs of all these patients being normal. Four patients had only localized radiological changes, which did not suggest generalized disease. Miller et al. (1959) reported clear chest radiographs in 8 of their 22 patients and remarked that dyspnoea did not always correlate with the radiographic findings.

Dyspnoea correlated well with a low diffusing capacity, especially when this was associated with restricted lung volumes. Four patients, who had no complaint of dyspnoea, were distinguished by having normal lung volumes and high normal forced expiratory volumes. This was especially marked in patient 15 , whose diffusing capacity was only $32 \%$ of his predicted normal and who could expire $95 \%$ of his vital capacity in one second.

The alveolar capillary block syndrome, characterized by normal lung volumes and normal ventilatory capacity and low diffusing capacity, was found in seven patients. Recent work on the treatment of systemic sclerosis with Versene (Rowell and Catterall, 1963) has shown that the diffusing capacity may be the most sensitive test of progress of the disease and of the effect of treatment.
The electrocardiographic tracings were remarkable for the fact that only in patient 15 were there signs of right ventricular strain. The abnormalities in the other tracings were variable or absent.

The importance of correct diagnosis in this disease is emphasized by patients 2 and 6 , who both received treatment for pulmonary tuberculosis by immobilization of the lung. This therapy was not only ineffective but also deleterious, as it helped to reduce even more the already restricted lung volumes and interfered with the mechanical function of the lungs.

\section{SUMMARY}

Sixteen patients with progressive systemic sclerosis (scleroderma) were fully investigated. Cough was reported by only two patients, though all but four of them complained of dyspnoea. When dyspnoea was the main symptom, it correlated with impairment of diffusing capacity and reduction in vital capacity. Some patients had normal vital capacities but low diffusing capacities, and when the ventilatory capacity was normal there was no complaint of dyspnoea.

The diffusing capacity was impaired in all patients, and the degree of impairment corresponded with the degree of dyspnoea and with diffuse fibrosis of the lung parenchyma found at three necropsies: there was no correlation with the radiological findings or with the E.C.G. The diffusing capacity test seemed to be the most sensitive indication of involvement of the lungs.

We wish to express our gratitude to all the physicians who referred patients to us, particularly to Dr. F. F. Hellier and Dr. S. T. Anning. Our thanks are also due to Mr. A. Pegg for the photographs.

\section{REFERENCES}

Baldwin, E. de F., Cournand, A., and Richards, D. W. (1949). Medicine (Baltimore), 28, 1.

Fennell, R. H., Rodnan, G. P., and Vazquez, J. J. (1962). Lab. Invest., $11,24$.

Finlay, D. W. (1891). Middx. Hosp. Rep., p. 29.

Marks, A., Cugell, D. W., Cadigan, J. B., and Gaensler, E. A. (1957). Amer. J. Med., 22, 51 .

Matsui, S. (1924). Mitt. med. Fak. Tokyo, 31, 55.

Miller, R. D., Fowler, W. S., and Helmholz, F. H. (1959). Proc. Mayo Clin., 34, 66.

Nice, C. M., Menon, A. N. K., and Rigler, L. G. (1959). Dis. Chest, 35,634 .

Ogilvie, C. M., Forster, R. E., Blakemore, W. S., and Morton, J. W. (1957). J. clin. Invest., 36, 1.

Rowell, N. R. (1962). Ann. rheum. Dis., 21, 70.

- and Beck, J. S. (1963). To be published.

- and Catterall, Mary (1963). To be published.

Salomon, A., Appel, B., Dougherty, E. F., Herschfus, J. A., and Segal, M. S. (1955). A.M.A. Arch. intern. Med., 95, 103.

Spain, D. M., and Thomas, A. G. (1950). Ann. intern. Med., 32, 152.

Tranquada, R. E., Simmons, D. H., and Miller, J. H. (1960). Arch.

intern. Med., 105, 607.
West, J. R., McĆlement, J. H., Carroll, D., Bliss, H. A., Kuschner, M., Richards, D. W., and Cournand, A. (1951). Amer. J. Med., 10, 156. 